\title{
UCRL 6452 Part I
}

\section{UNIVERSITY OF CALIFORNIA}

Ernest O. Saurence
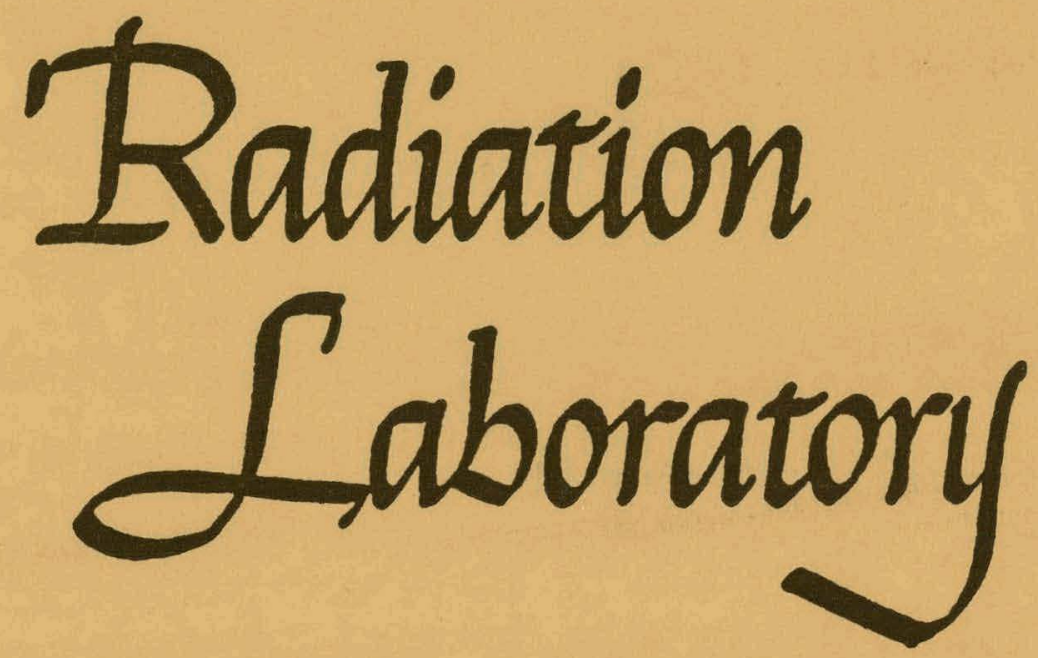

LIVERMORE SITE 


\section{DISCLAIMER}

This report was prepared as an account of work sponsored by an agency of the United States Government. Neither the United States Government nor any agency Thereof, nor any of their employees, makes any warranty, express or implied, or assumes any legal liability or responsibility for the accuracy, completeness, or usefulness of any information, apparatus, product, or process disclosed, or represents that its use would not infringe privately owned rights. Reference herein to any specific commercial product, process, or service by trade name, trademark, manufacturer, or otherwise does not necessarily constitute or imply its endorsement, recommendation, or favoring by the United States Government or any agency thereof. The views and opinions of authors expressed herein do not necessarily state or reflect those of the United States Government or any agency thereof. 


\section{DISCLAIMER}

Portions of this document may be illegible in electronic image products. Images are produced from the best available original document. 


\section{UNIVERSITY OF CALIFORNLA}

Lawrence Radiation Laboratory

Livermore, California

Contract No. W-7405-eng-48

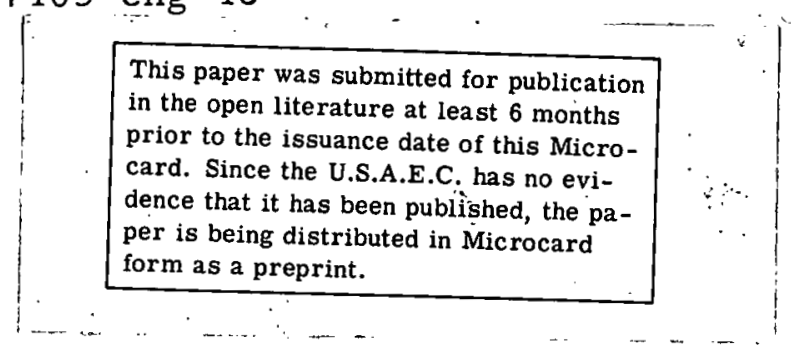

STUDIES ON BISMUTH ALLOYS。I.

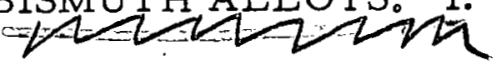

LIQUIDUS CURVES OF THE Bi-Cu, Bi-Ag, AND Bi-Au SYSTEMS

Marcel W. Nathans and Marjorie Leider

May 22, 1961

Facsimile Price $\$ 160$
Microfilm Price $\$ \quad 80$
Avoilable from the
Office of Technicol Services
Deportment of Commerce
Woshington 25, D. C.

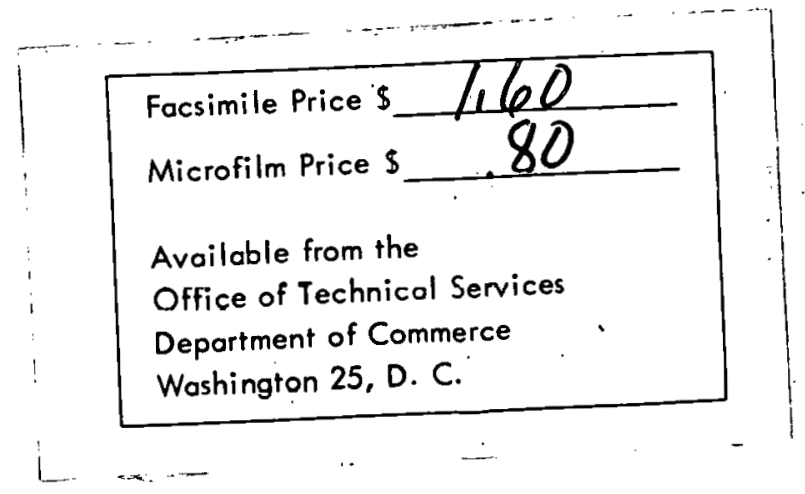


UCRL- 6452

Part I
$-2-$

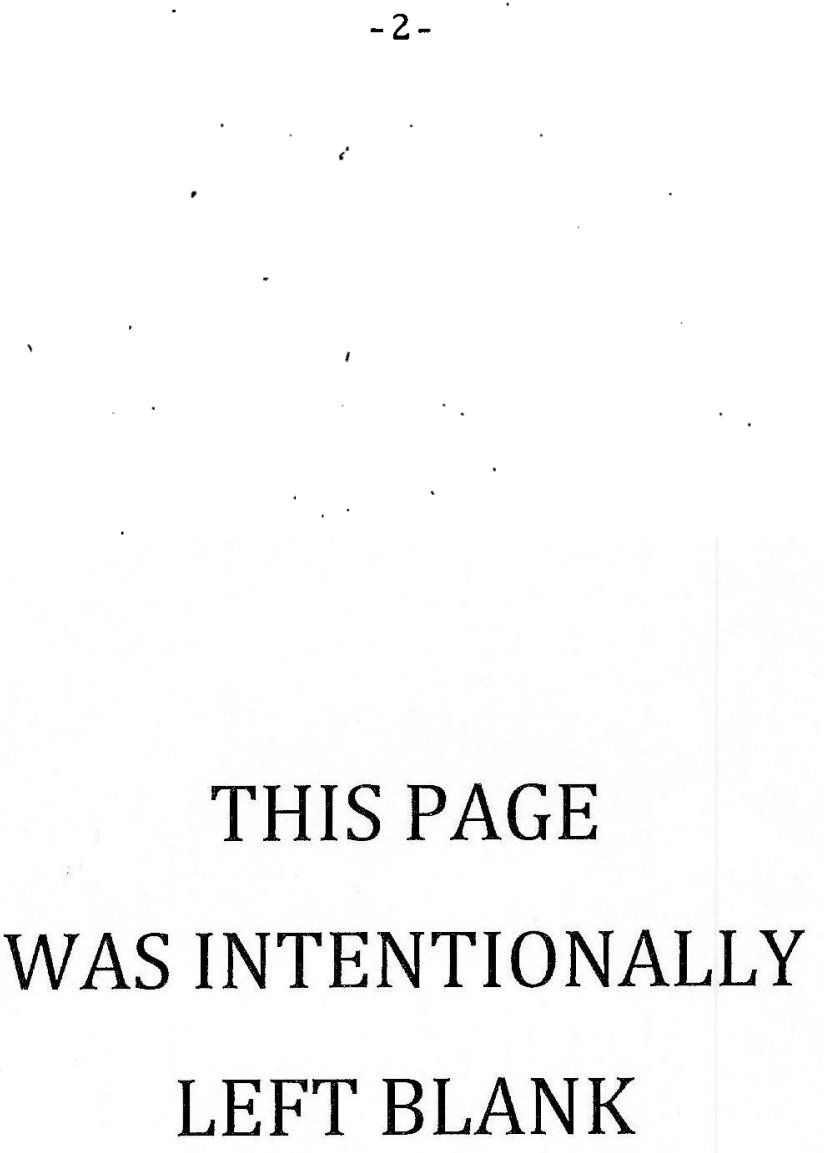

LEFT BLANK 


\section{STUDIES ON BISMUTH ALLOYS. I.} LIQUIDUS CURVES OF THE Bi-Cu; Bi-Ag, and Bi-Au SYSTEMS* Marcel W. Nathans and Marjorie Leider

Lawrence Radiation Laboratory, University of California Livermore, California

May 22, 1961

\section{ABSTRACT}

The liquidu's curves of the $\mathrm{Bi}-\mathrm{Cu}, \mathrm{Bi}-\mathrm{Ag}$, and $\mathrm{Bi}-\mathrm{Au}$ systems were redetermined by means of a sampling method. The Bi-Ag curve was somewhat shifted from the previously determined location. The eutectic was found at $262.5 \pm 0.2^{\circ} \mathrm{C}$ at $4.95 \pm 0.05$ atom $\%$ silver $(2.62$ wt $\%)$. The Bi-Cu liquidus agreed fairly well with Kleppa's data over the range investigated by him. The discrepancies in the literature in regard to higher copper concentrations were resolved. The eutectic was determined to be at $270.6 \pm 0.1^{\circ} \mathrm{C}$ at 0.46 atom \% copper $(0.14$ wt \%)." The Bi-Au liquidus did not agree well with the few experimental data available. Below the peritectic temperature, a completely new liquidus curve was established. The peritectic was found to be at $371 \pm 2^{\circ} \mathrm{C}$ by means of differential thermal analysis: The composition is 23.1 atom $\%$ gold $(24.1$ wt $\%)$. The eutectic is at $13.4 \pm 0.2$ atom $\%$ gold (14.1 wt $\%)$ at $241.5 \neq 0.5^{\circ} \mathrm{C}$.

\footnotetext{
* Work performed under the auspices of the U. S. Atomic Energy.Commission.
} 
UCRL- 6452 .

$-4-$

Part I

The heats of fusion of the four elements agreed reasonably well with the literature values, except that of bismuth.

The results show that the sampling method is, for many cases, well adapted for the determination of liquidus curves. 
STUDIES ON BISMUTH ALLOYS. I.

LIQUIDUS CURVES OF THE Bi-Cu, Bi-Ag, and Bi-Au SYSTEMS

Marcel W. Nathans and Marjorie Leider

Lawrence Radiation Laboratory, University of California

Livermore, California

\section{Introduction}

During an investigation of the distribution of small amounts of ternary additions to binary systems involving bismuth, it was found that liquidus data were obtained which differed from those reported in the literature. It was, therefore, considered useful to examine the systems involved a little more in detail. We are reporting here the results of our liquidus determinations of the binary systcms of bismuth with copper, silver, and gold.

These three systems were investigated many years ago by means of thermal analysis. The results are summarized by Hansen and Anderko. The $\mathrm{Bi}-\mathrm{Cu}$ system has been investigated by Jeriomin, ${ }^{2}$ Hiorns, ${ }^{3}$ Portevin, ${ }^{4}$ and Heycock and Neville ${ }^{5}$ as well as by Kleppa ${ }^{6}$ and others.

1M. Hansen and K. Anderko, "Constitution of Binary Alloys," 2nd edition, McGraw Hill, New York, 1958.

${ }^{2}$ K. Jeriomin, Z. anorg. Chem., 55, 412 (1907).

A. H. Hiorns, Trans. Faraday Soc., 1, 179 (1905).

${ }^{4}$ A. Portevin, Rev. met.. 4, 1077 (1907).

${ }^{5}$ C. T. Heycock and F. H. Neville, Phil. Trans. Roy. Soc. London, Al89. $46(1897)$.

${ }^{6}$ O. J. Kleppa, J. Am. Chem. Soc. 74, 6050 (1952). 
Although the oldest, Heycock and Neville's work stands among the most precise thermal analyses ever done. Unfortunately, their investigations cover only very dilute solutions.

Kleppa used a sampling method which was quite adequate, but he, too, did not cover the complete liquidus range. Among the various determinations by thermal analysis, the work of Jerlomin and of IIeycoele and Noville is the most consistent. Kleppai's dảa do not enlirely aglee with thooc of Jerıomiñ. The sampling data lie above Jeriomin's liquidus.

The cutcctic point has been reported at about $0.6^{\circ}$ below the melting point of bismuth ${ }^{7}$ and about 0.7 atom $\%$ bismuth by Heycock and Neville, ${ }^{7}$ and at 0.48 atom \% bismuth by Kleppa. 6

The Bi-Ag liquidus has been investigated by Heycock and Neville $5,7,8$ and by Petrenko. 9 Only the latter' author covered the entire liquidus range. Recently a portion has been examined by Kleppa. ${ }^{10}$ Petrenko reports a eutectic at $262^{\circ} \mathrm{C}$ and 95.3 atom \% bismuth.

The $\mathrm{Bi}-\mathrm{Au}$ system was investigated by $\mathrm{Vogel}_{0}^{11}$ who reported a eutectic at $240^{\circ} \mathrm{C}$ and 81.1 atom \% bismuth. Later, an incongruently melting compound, $\mathrm{Au}_{2} \mathrm{Bi}$, was found by de Has and Jurriaanse. 12 The peritectic was

${ }^{7}$ C. T. Heycock and F. H. Neville, J. Chem. Soc., 61, 893 (1892).

${ }^{8}$ C. T. Heycock and F. H. Neville, J. Chem. Soc., 65, 73 (1894).

${ }^{9}$ G. I. Petrenko, Z, anorg. Chem., 50, 136. (1906).

${ }^{10}$ O. J. Kleppa, J. Phys. Chem. 60, 446 (1956).

${ }^{11}$ R. Vogel, Z, anorg. Chem., 50, 145 (1906).

${ }^{12}$ W. J. de Haas and F. Jurriaanse, Naturwissenschäften, 19, 706 (1931). 
stated to be at $373^{\circ} \mathrm{C} .^{13}$ The fact that Vogel did not observe the peritectic can be explained by the small number of his data and the apparent sluggishness of the formation of $\mathrm{Au}_{2} \mathrm{Bi}$.

The method which we have used consisted of sampling the liquid phase and analyzing the sample. In all cases known to us, sampling yields liquidus curves which, at best, coincide with curves obtained from thermal analysis. Generally, however, curves obtained by sampling lie higher than those obtained by thermal analysis. (See, for example, a number of cases cited by Nathans. ${ }^{14}$ ) We believe that the sampling method yields more reliable data, because it is a direct measurement under equilibrium conditions, provided that the existence of equilibrium can be ascertained and that a clear separation of the two phases can be effected.

\section{Experimental Equipment}

The apparatus was a stainless-steel furnace tube with a gas inlet at the bottom, a cooling coil at the top, a flanged head having an opening for a stirrer, a thermocouple well, and a sampling tube. All seals were made by means of O-rings or garlock gaskets. Sampling was done with 2-or 3-mm i. di. pyrë̈ or quartz tubes with a piece of porous graphite (National Carbon Co. grade 60) press-fitted into one end to serve as a filter. Figure 1 shows the arrangement for inserting and withdrawing the sample tube from the melt. A Norton high-purity alumina crucible contained the melt. The crucible was located inside a graphite secondary with a heavy graphite top as an oxygen getter. The top had suitably located holes for the stirrer etc. The assembly

\footnotetext{
${ }^{13}$ F. Jurriaanse, Z. Krist., 90, $322 \cdot(1935)$.

${ }^{14}$ M. W. Nathans; AEC Rept. No. ANL-5753, July 1957.
} 
was inserted in a Kanthal-wound Hevi-Duti clam shell type furnace, 3-inches i.d. and 18-inches long placed on end. Provisions were made to evacuate or pressurize the furnace or the sampling tube.

Temperatures were measured with a $\mathrm{Pt}-\mathrm{Pt}(10 \% \mathrm{Rh})$ thermocouple with its cold junction in an ice-bath. The thermocouple was calibrated at the melting points of copper, aluminum, zinc, lead, and tin (INBS certified). and at the boiling points of $\mathrm{p}$-dichlorobenzene and water. The calibration was checked periodically, but no change greater than $0.2 \mu \mathrm{V}$ was observed. The temperatures were read to $0.1^{\circ} \mathrm{C}$ with a Rubicon model 2745 potentiometer.

\section{Procedure}

A charge of between 400 and 500 grams was placed in the crucible. In a number of experiments, about 60 to 100 milligrams of a ternary addition was present as a radioactive tracer so that data of the type described in a subsequent article ${ }^{15}$ could be obtained simultaneously. The effect of this small amount of impurity on the binary liquidus is negligible.

After loading and emplacement, the furnace was flushed with highpurity nitrogen. Throughout an experiment, the pressure in the furnáce was kept about $250 \mathrm{~mm}$ above atmospheric by means of nitrogen in order to impede the diffusion of small amounts of air through small leaks. The Bi-Cu and $\mathrm{Bi}-\mathrm{Ag}$ melts were stirred with a tungsten rod flattened at the lower end. Stirring was usually continued during sampling. Bi-Au melts were agitated periodically with the thermocouple well to prevent pick-up of the stirrer metal by the melt. Agitation by gas bubbling through a tube was tried, but later abandoned because the bubble rate was rather difficult to control.

\footnotetext{
${ }^{15} \mathrm{M}$. W. Nathans and M. Leider, to be published.
} 
Although no record was kept of whether the melt was stirred during sampling or not, it was concluded from plots of the data that it did not matter. No particles passed the filter to a detectable degree. This was also checked on a couple of occasions by taking a sample without filter after a suitable settling period.

The charge was generally heated to about $100^{\circ} \mathrm{C}$ above the estimated liquidus temperature and kept there for at least thirty minutes. One or two samples were taken to check the composition of the melt. Further samples were taken at successively lower temperatures by pressurizing the melt, by suction on the sampling tube, or both. Cantrol of the sample size was: usually poor. Most sample weights varied between 5 and 15 grams. The sample size usually became smaller when a large amount of precipitate had formed. This was probably caused by the increased viscosity of the mass. Experiments in the $\mathrm{Bi}-\mathrm{Cu}$ and $\mathrm{Bi}-\mathrm{Ag}$ systems above $600^{\circ} \mathrm{C}$ were car ried out under a layer of purified flake graphite as additional insurance against oxygen pick-up by the melt. In these experiments, it is often impossible to obtain good samples, probably in part because the filter became clogged when the sampling tube passed through the graphite layer. The filter could be reopened, however, by blowing nitrogen through it prior to forcing 'a sample through.

\section{Analytical}

In each.case, the entire sample was dissolved in either $8 \mathrm{~N}$ to $10 \mathrm{~N} \mathrm{HNO}_{3}$. or in aqua regia. (when gold was present). The samples were analyzed for both components except when a large excess of one interfered with the analysis of the other.

Bismuth was determined by titration with EDTA (about $0.01 \mathrm{~N}$ ). Aliquots containing about $20 \mathrm{mg}$ of bismuth were added to a solution having a $\dot{\mathrm{p}}_{\mathrm{H}}$ less 


\section{Part I}

than 2, and containing a few grams of thiourea as indicator and complexing agent. The titrations were carried out at a $p_{H}$ between 2.1 and 2.4. The accuracy was quite sensitive to the $\mathrm{p}_{\mathrm{H}}$.

Copper was determined electrolytically. A separation from bismuth must be carried out first. This was done by carefully neutralizing the solution with ammonia to a $p_{H}$ of 6 to $/ 7$ tollowed by the addiliun of antifierium carbonate to complex the copper ion. The precipitate was filtered off. A complete separation from bismuth can be effected by redissolving the precipitate in nitric acid and treatment with ammonium hydroxide and ammonium carbonate, a second and a third time.

In later samples, copper was determined spectrophotometrically with a Carey recording spectrograph. The 807-millimicron band was found suitable. Bismuth did not interfere, but the intensity was dependent upon the nitric acid concentration. The acid variation was held șmall, however, by diluting a suitable aliquot with a forty-fold volume of $2 \mathrm{~N}$ nitric acid in a volumetric flask. The effect of dust particles in the acid was eliminated by letting the solutions stand overnight and transferring them to the cells with a transfer pipette.

Silver was determined electrolytically in an ammoniacal solution from its EDTA complex. Bismuth did not interfere. Gold was determined coulometrically with a controlled-potential coulometer. 16

All analyses had a precision of better than $\pm 1 \%$. Material balances were, in all but a few isolated cases, between 99 and $100.5 \%$.

\footnotetext{
$16 \mathrm{~J}$. Harrar, J. Electroanal. Chem., to be published.
} 


\section{Materials}

Bismuth: $99.999 \%$ pure droplets from American Smelting and Refining Co., melting point $271.4^{\circ} \mathrm{C}$.

Copper: OFHC copper from ștock, melting point $1083^{\circ} \mathrm{C}$.

Silver: $99.99 \%$ pure needles from Fairmont Chemical Co., melting point $961^{\circ}$.

Gold: $\quad 99.95 \%$ pure scrap from stock. The major impurities are (spectrographic): $0.003-0.03 \% \mathrm{Ag}, 0.003-0.03 \% \mathrm{Pd}, 0.001-$ $0.01 \% \mathrm{~Pb}, 0.001-0.01 \% \mathrm{Cu}$.

\section{Results}

The results are shown in Figs: 2 through 4. Rather than tabulating our actual experimental data, we show in Tables I through III data as read from. the smoothed curves before reproduction. We have also indicated the mean deviation of the experimental data from the curves.

The few points obtained during reheating agree well with those obtained during cooling. The deviation from the curve of points obtained by thermal analysis is small.

It appears that at higher copper contents, the copper precipitate is rather fine and does not settle rapidly. Samples were taken without a filter from a composition containing about $95 \%$ copper. The analyses showed too high a copper content which indicates poor phase separation.

In the gold-bismuth system, the sampling data near the peritectic were quite erratic. Our explanation is that the rate of formation of the compound is slow, and that there is still some tendency for pure gold to precipitate as a metastable phase. This could explain why Vogel did not observe the change in slope of the liquidus. ${ }^{11}$ 
An attempt was made to obtain sampling data on the bismuth-rich side of the silver-bismuth eutectic. We got only one point by sampling but were able to get two points by thermal analysis. We feel that this was sufficient to establish this part of the liquidus to about $5 \%$ relative to the silver content.

The eutectic data are shown in Table IV. They are the average of three separate determinations, including in the case of Bi-Ag d deleswlination from the bismuth-rich side.

The Au-Bi peritectic can be established by the intersection of the two parts of the liquidus. It was determined scparately, however, with a sample containing about 80 wt $\% \mathrm{Au}_{2} \mathrm{Bi}$ and $20 \%$ gold. This sample was obtained by treating an ingot with $8 \mathrm{~N}$ nitric acid. It was subjected to differential thermal analysis with aluminum powder as the inert in a dynamic argon atmosphere and at an upheat rate of $10^{\circ} \mathrm{C}$ per minute. Figure 4 shows the record. Concurrently, the temperature of the sample was measured with a potentiometer. The peritectic was established at $371 \pm 2{ }^{\circ} \mathrm{C}$.

The agreement of the liquidus points with the older data is fair to poor, but the agreement is good with Kleppa's data. The validity of the data was checked by calculating the heats of fusion from the terminal slope of a log (atom \% solute) vs $1 / \mathrm{T}$ plot. . We estimated the distribution coefficient of $\mathrm{Bi}$ between solid and liquid Äg as 0.1 from the data given by Hansen and Anderko. ${ }^{1}$ Solid solubility was neglected in the remaining cases. Table V shows a comparison between our calculated values and those found in Hultgren's compilation. $^{17}$. The data agree well, except for bismuth. This may warrant further investigation.

${ }^{17}$ R. Hultgren, Project Supervisor, "Selected Values, Thermo-dynamic Properties of Metals, "Prepared for the USAEC at the Minerals Res. Lab., University of California, 1956. 
Acknowledgments. We wish to acknowledge the valuable help and sug gestions afforded us by the following members of the analytical laboratory: Dr. R. Bystroff, for his help with the spectrophotometric copper determination, Dr. J. Harrar, for his help with the coulometric gold determination, and Mrs. G. Stephas. 
Part. I

TABLE I

SMOOTHED LIQUIDUS DATA FOR THE Cu-Bi SYSTEM ${ }^{2}$

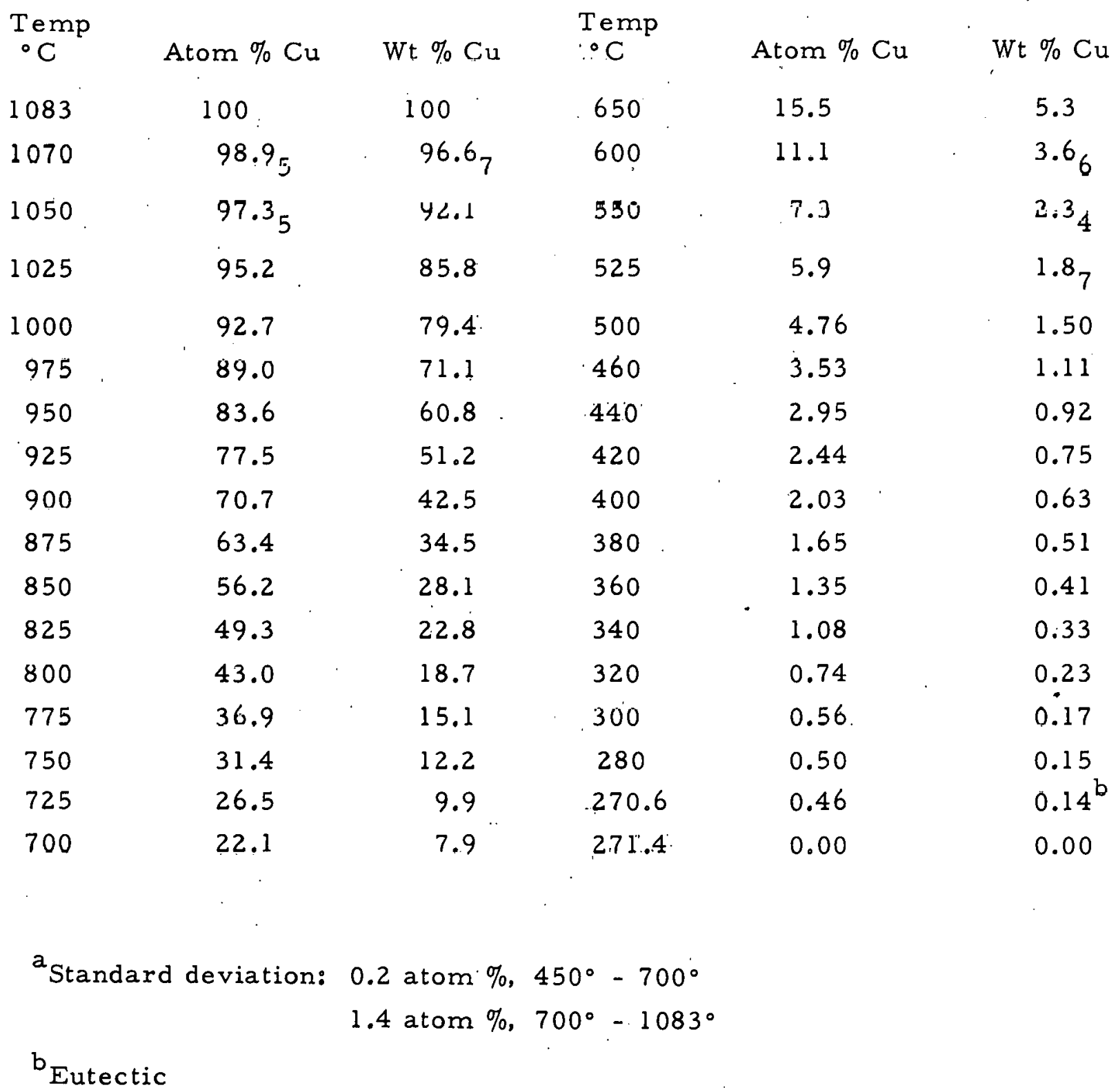


TABLE II SMOOTHED LIQUIDUS DATA FOR THE Ag-Bi.SYSTEM ${ }^{2}$,

\begin{tabular}{|c|c|c|c|c|c|}
\hline $\begin{array}{l}\text { Temp } \\
{ }^{\circ} \mathrm{C}\end{array}$ & Atom $\% \mathrm{Ag}$ & $\mathrm{Wt} \% \mathrm{Ag}$ & $\begin{array}{l}\text { Temp } \\
{ }^{\circ} \mathrm{C}\end{array}$ & Atom $\% \mathrm{Ag}$ & Wt $\% \mathrm{Ag}$ \\
\hline 961 & 100 & 100 & 460 & 53.1 & 36.9 \\
\hline 950 & 99.1 & 98.3 & 450 & 50.0 & 34.0 \\
\hline 925 & 94.9 & 90.6 & 430 & 42.4 & 27.5 \\
\hline 850 & 90.8 & 83.6 & 420 & 38.3 & 24.3 \\
\hline 800 & 86.7 & 77.1 & 410 & 34.7 & 21.5 \\
\hline 750 & 83.2 & 71.9 & 400 & 31.0 & 18.8 \\
\hline 700 & 80.1 & 67.5 & 390 & 27.2 & 16.2 \\
\hline 650 & 7.6 .6 & 61.5 & 380 & 23.7 & 13.8 \\
\hline 600 & 72.6 & 57.5 & 360 & 17.6 & 9.9 \\
\hline 575 & 70.2 & $54.9^{\circ}$ & 340 & 13.2 & 7.3 \\
\hline 550 & 67.6 & 51.9 & 320 & $10.0_{5}$ & $5.4_{5}$ \\
\hline 520 & 63.9 & 47.7 & 300 & $7.7_{7}$ & $4: 17$ \\
\hline 500 & 61.1 & 44.8 & 280 & $6.0_{8}$ & 3.23 \\
\hline \multirow[t]{2}{*}{480} & 57.9 & 41.5 & 270 & $5.4_{2}$ & $2.8_{7}$ \\
\hline & & & 262.5 & 4.95 & $2.62^{b}$ \\
\hline
\end{tabular}

\footnotetext{
atandard deviation: 0.3 atom $\%, 260^{\circ}-400^{\circ}$

0.1 atom $\%, 400^{\circ}-960^{\circ}$

${ }^{\mathrm{b}}$ Eutectic
} 
TABLE III

SMOOTHED LIQUIDUS DATA FOR THE Au-Bi SYSTEM ${ }^{2}$

$\begin{array}{cccccc}\begin{array}{c}\text { Temp } \\ { }^{\circ} \mathrm{C}\end{array} & \text { Atom } \% \text { Au } & \text { Wt } \% \text { Au } & \begin{array}{c}\text { Temp } \\ { }^{\circ} \mathrm{C}\end{array} & \text { Atom } \% \text { Au } & \text { Wt } \% \text { Au } \\ 1063 & 100 & 100 & 450 & 41.2 & 39.8 \\ 1050 & 98.8 & 98.7 & 400 & 35.9 & 34.6 \\ 1000 & 94.5 & 94.2 & 371 & 33.1 & 31.8^{\mathrm{U}} \\ 950 & 90.4 & 89.9 & 350 & 27.0 & 23.9 \\ 900 & 86.4 & 85.7 & 325 & 23.0 & 22.0 \\ 850 & 82.5 & 81.6 & 300 & 19.8 & 18.9 \\ 800 & 78.5 & 76.5 & 270 & 16.4 & 15.6 \\ 750 & 74.4 & 73.3 & 241 & 13.2 & 12.6 \mathrm{C} \\ 700 & 69.9 & 68.7 & 250 & 10.0 & 9.5 \\ 650 & 64.6 & 63.3 & 260 & 6.0 & 5.7 \\ 600 & 59.0 & 57.5 & 270 & 0.9 & 0.8 \\ 550 & 52.9 & 51.5 & 271.4 & 0 & 0 \\ 500 & 46.7 & 45.3 & & & \end{array}$

${ }^{a}$ Standard deviation: 0.3 atom $\%, 240^{\circ}-371^{\circ}$

0.5 atom $\%, 371^{\circ}-700^{\circ}$

0.2 atom $\%, 700^{\circ}=\ln 65^{\circ}$

${ }^{b}$ Peritectic

${ }^{c}$ Eutectic 


\section{TABLE IV}

\section{EUTECTIC TEMPERATURES AND COMPOSITIONS}

\begin{tabular}{llll} 
& \multicolumn{1}{c}{ Temp } & \multicolumn{2}{c}{ Composition } \\
& ${ }^{\circ} \mathrm{C}$ & Atom $\% \mathrm{Bi}$ & Wt $\%$ Bi \\
$\mathrm{Bi}-\mathrm{Cu}$ & $270.6 \pm 0.1$ & 99.54 & 99.86 \\
$\mathrm{Bi}-\mathrm{Ag}$ & 262.5 & $95.0_{5}$ & 97.38 \\
$\mathrm{Bi}-\mathrm{Au}$ & $241.1 \pm 0.3$ & $86.8 \pm 0.2$ & 86.1
\end{tabular}

TABLE V

HEATS OF FUSION OF $\mathrm{Cu}, \mathrm{Ag}, \mathrm{Au}$, and $\mathrm{Bi}$

$\begin{array}{ccccc}\text { Element } & \mathrm{Cu} & \mathrm{Ag} & \mathrm{Au} & \mathrm{Bi} \\ \Delta \mathrm{H}_{\mathrm{m}}{ }^{\mathrm{a}} \text { Calculated } & 2940 & 2780 & 2870 & 3130^{\mathrm{b}} \\ \Delta \mathrm{H}_{\mathrm{m}}^{\mathrm{a}} \text { Literature } & 3120 & 2855 & 2955 & 2600\end{array}$

${ }^{a}$ Calories per gramatom

${ }^{b}$ Average of values 3100,3300 , and 3000 from the $\mathrm{Cu}-\mathrm{Bi}, \mathrm{Ag}-\mathrm{Bi}_{9}$ and Au-Bi systems respectively 
Part I

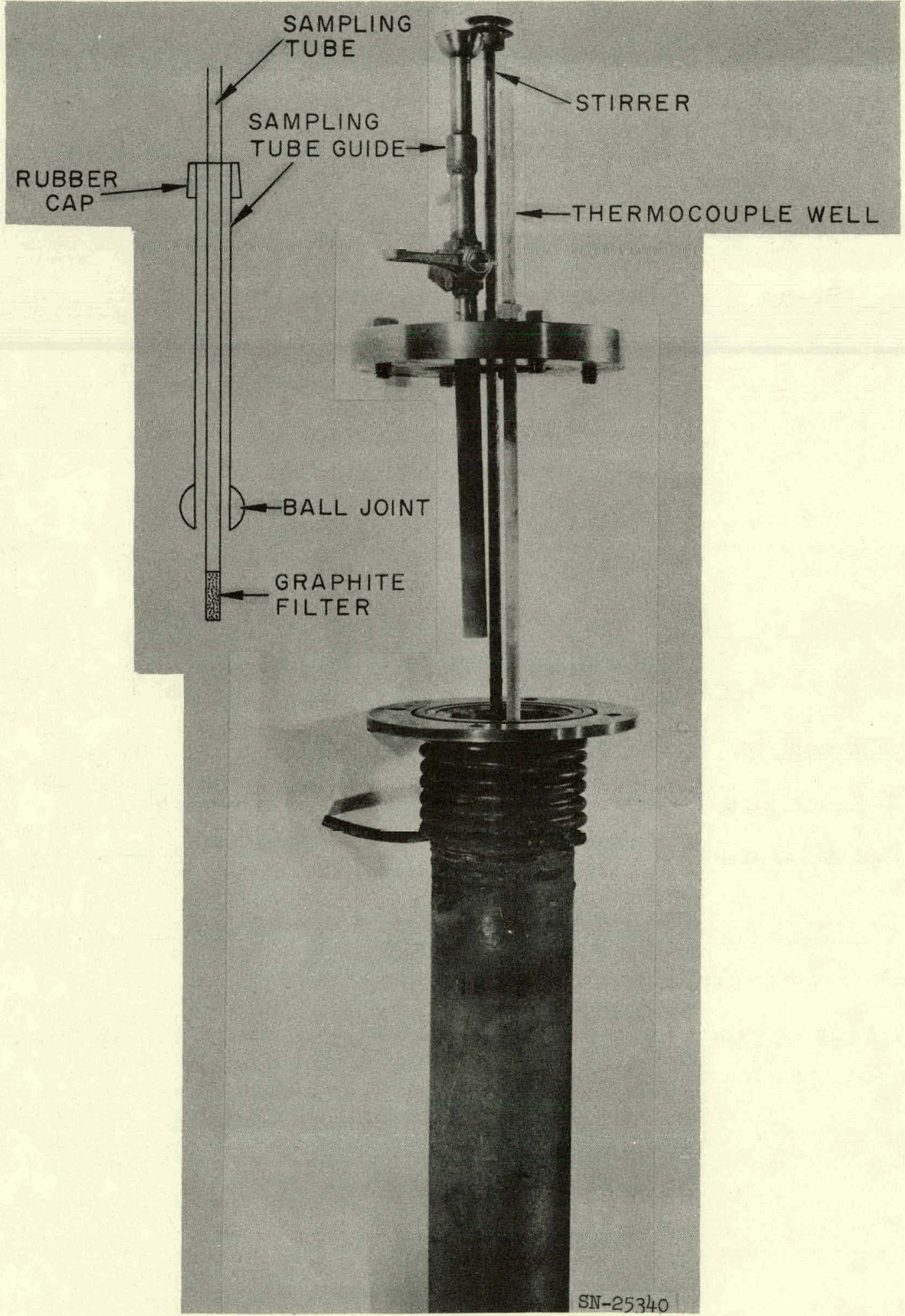

Fig. 1. Furnace closure with sampling arrangement. 


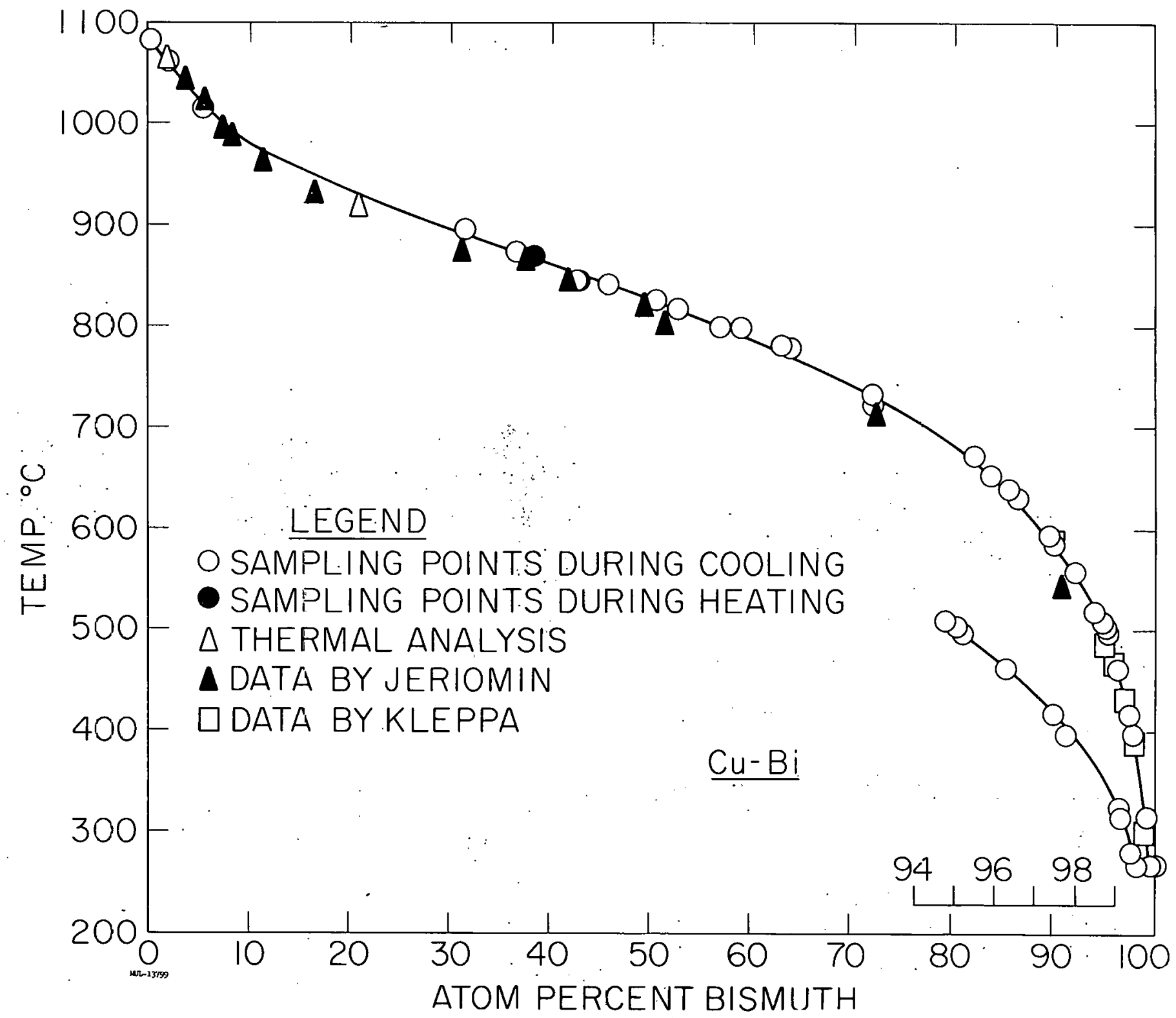

Fig. 2. Liquidus of the bismuth-copper system. 


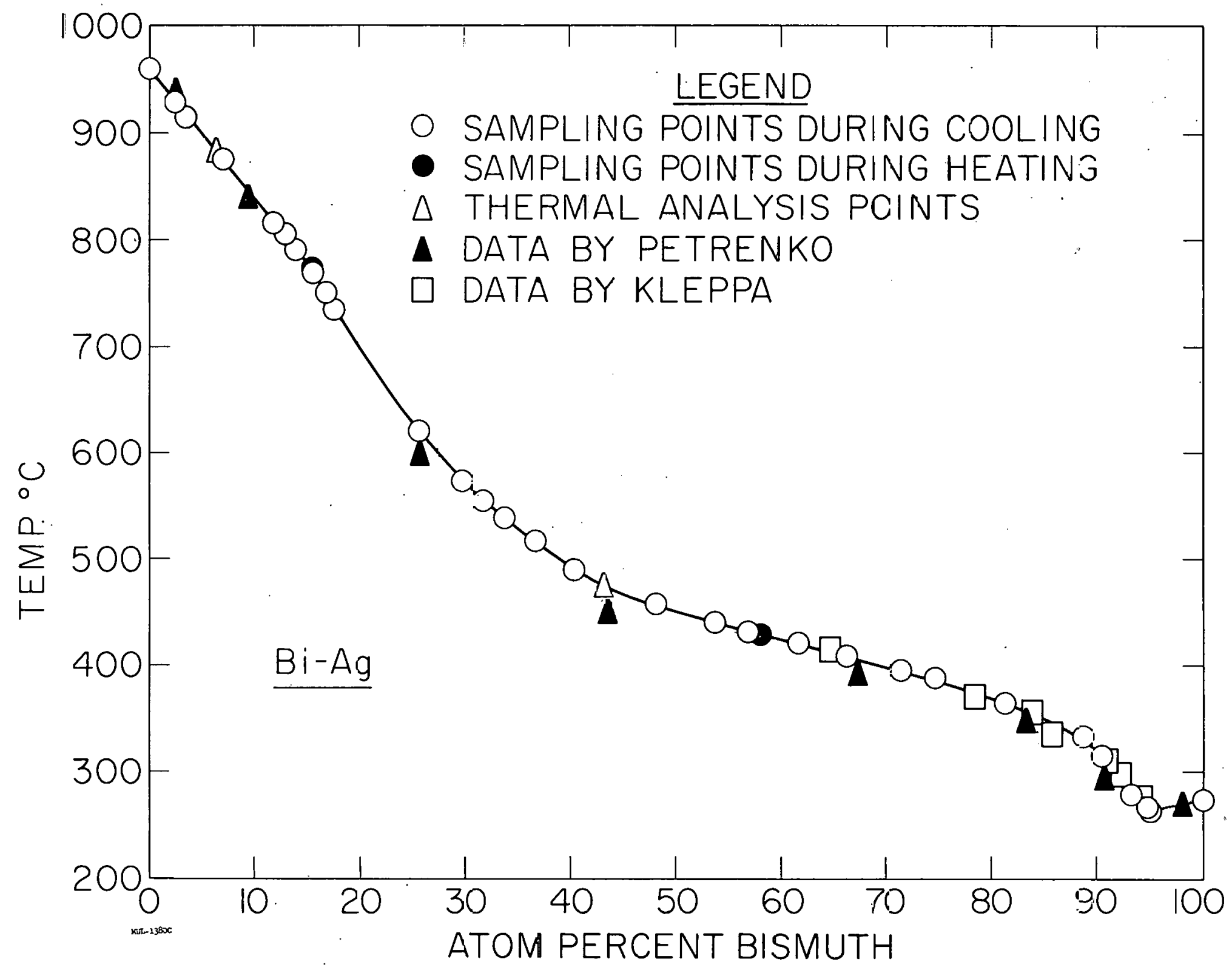

Fig. 3. Liquidus of the bismuth-silver system. 


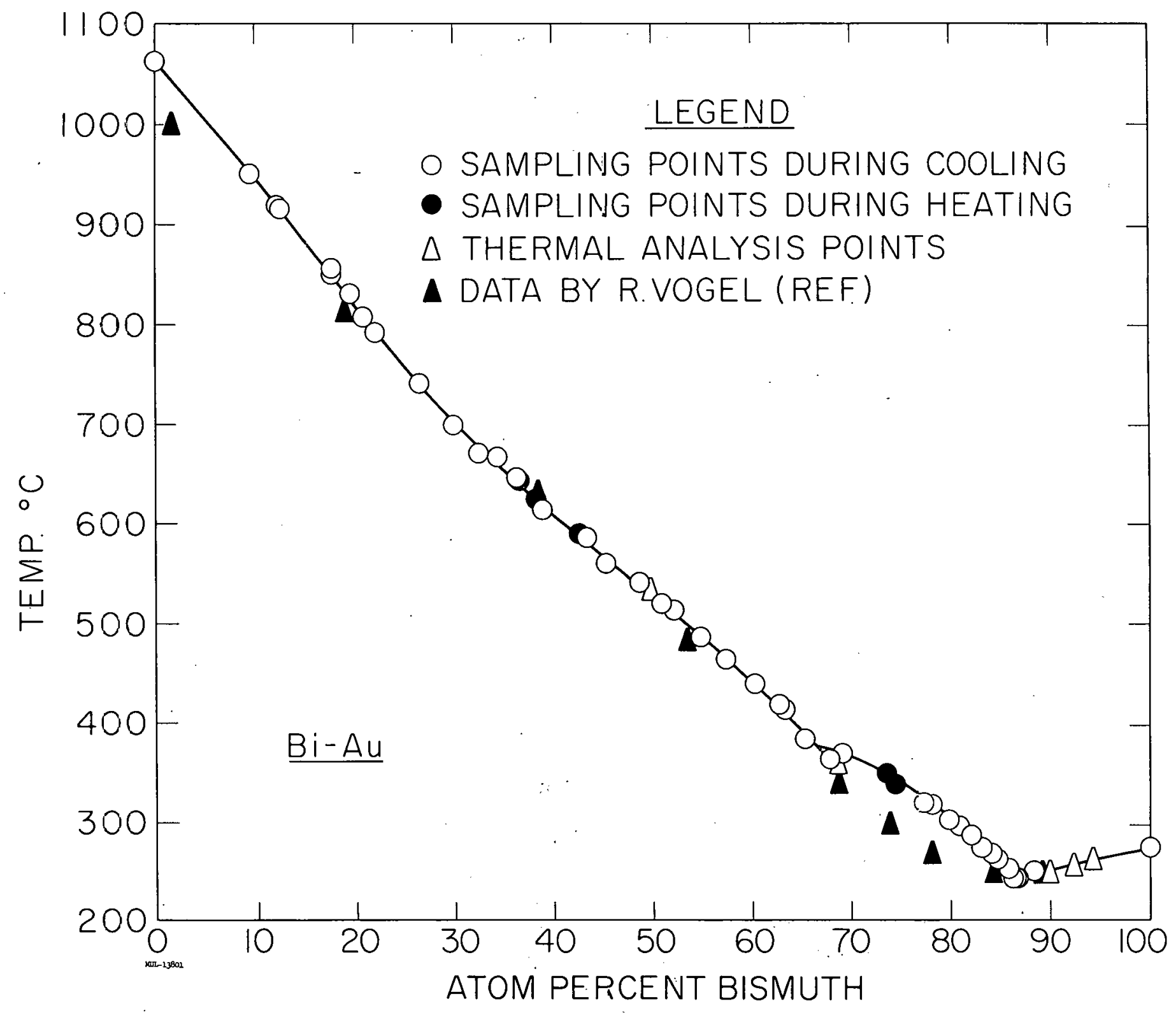

Fig. 4. Liquidus of the bismuth-gold system. 
This report was prepared as an account of Government sponsored work. Neither the United States, nor the Commission, nor any person acting on behalf of the Commission:

A. Makes any warranty or representation, expressed or implied, with respect to the accuracy, completeness, or usefulness of the information contained in this report, or that the use of any information, apparatus, method, or process disclosed in this report may not infringe privately owned rights; or

B. Assumes any liabilities with respect to the use of, or for damages resulting from the use of any information, apparatus, method or process disclosed in this report.

As used in the above, "person acting on behalf of the Commission " includes any employee or contractor of the commission, or employee of such contractor, to the extent that surh employee or contractor of the Commission, or employee of such contractor prepares, disseminates, or provides access to, any information pursuant to his employment or contract with the Commission, or his employment with such contractor. 